\title{
Establishment of an Alzheimer's disease model with latent herpesvirus infection using PS2 and Tg2576 double transgenic mice
}

\author{
Seiichi TANAKA ${ }^{1)}$ and Hiroshi NAGASHIMA ${ }^{2)}$ \\ 1) Center for Experimental Animals, Fukuoka University, 7-45-1 Nanakuma, Jonan-ku, Fukuoka-shi, Fukuoka \\ 814-0180, Japan \\ 2) Animal-care Co., Ltd., 5-18-14 Shinjuku, Shinjuku-ku, Tokyo 160-0022, Japan
}

\begin{abstract}
A relationship between Alzheimer's disease and herpes simplex virus infection has been pointed out. We established a model of Alzheimer's disease with a latent herpesvirus infection using a mouse model of Alzheimer's disease (PS2Tg2576) and examined the changes in amyloid $\beta$ (A $\beta$ ) in the brain. We crossbred female PS2 mice with male Tg2576 hemi mice and chose PS2Tg2576 mice. After priming 5-week-old male mice with anti-pseudorabies virus swine serum, we challenged the mouse with 100 LD $_{50}$ of YS-81, a wild-type strain of pseudorabies virus. The viral DNA was detected in nasal swabs by a reactivation test and in the trigeminal ganglia. At two months after infection, the $A \beta 40$ and $A \beta 42$ levels in the brains of the mice of the latently infected group were increased; the increase was greater than that observed in the noninfected group. Latent pseudorabies virus infection was established in PS2Tg2576 mice and the level of A $\beta$ increased with the reactivation of the latent virus.
\end{abstract}

Key words: Alzheimer's disease, herpesvirus, latent infection, pseudorabies virus

\section{Introduction}

Dementia is one of the most serious health conditions affecting the world's elderly population [20, 51]. In 2012, $14 \%$ of elderly individuals ( $>65$ years of age) in Japan showed symptoms of dementia $[20,51]$. This ratio is expected to increase to $20 \%$ in 2025 [20,51]. More than $50 \%$ of dementia patients have Alzheimer's disease (AD) $[20,51]$. Thus, $\mathrm{AD}$ is the most important disease target in dementia treatment.

$\mathrm{AD}$ has been investigated for more than 100 years. The initial symptom of AD is memory loss, the severity of which gradually increases with time; this is accompanied by disorientation and by disorder in the ability to make decisions [3, 4]. Dementia progresses steadily, with patients ultimately becoming bedridden [2]. Complications (such as pneumonia) develop over the course of 5-15 years, thus leading to a fatal outcome [14]. Its neuropathological characteristics, mainly amyloid plaques and neurofibrillary tangles, have been examined in the brains of $\mathrm{AD}$ patients $[17,24,39]$. Amyloid plaques are constructed from amyloid $\beta(\mathrm{A} \beta) 40$ and 42 $[40,43]$. $A \beta 42$ is more aggregative than $\mathrm{A} \beta 40[18]$.

The viruses of alphaherpesvirinae, one of the three subfamilies of herpesviridae, persist in an inactive state, primarily in the neural tissues and mainly within the neurons of the ganglia, for varying durations $[1,42]$ and avoid the host's immune response [9, 32, 34, 41]. These

(Received 12 June 2017 / Accepted 8 November 2017 / Published online in J-STAGE 29 November 2017)

Address corresponding: S. Tanaka, Center for Experimental Animals, Fukuoka University, 7-45-1 Nanakuma, Jonan-ku, Fukuoka-shi, Fukuoka 814-0180, Japan 
latent viruses are often reactivated by stress [33, 34, 41]. Herpesvirus infection results in a long-term course of recurrent disease [46]. Thus, the establishment of latent infection is an interesting feature of all herpesviruses [46]. Animal models provide experimental systems that can be used to elucidate the molecular mechanisms of latent viral reactivation $[46,47]$.

Herpes simplex virus (HSV) is a member of the alphaherpesvirinae subfamily [22]. HSV infects humans and causes several diseases, including herpes labialis, corneal herpes, and herpes encephalitis [10]. Over the past 30 years, a large number of studies have reported a relationship between AD and HSV [5, 26, 33]. However, the mechanisms underlying this pathogenic association have not been fully clarified. In 2009, AD and HSV infection were suggested to be related [52]. It was also demonstrated that $A \beta$ accumulated in cells and mouse brains infected with HSV type 1 [52]. However, it is unlikely that primary herpesvirus infection causes $\mathrm{AD}$ because dementia typically occurs in elderly patients who are likely to have already been infected with some type of herpesvirus; thus, latent infection should be considered.

We previously showed that latent pseudorabies virus (PRV) infection in swine was reactivated by treatment with acetylcholine both in vivo and in vitro [46]. We also established a model of latent PRV infection in BALB/c mice with YS-81, a wild-type strain of PRV [47]. Mice were pretreated with anti-PRV swine serum and then challenged with YS-81 based on a procedure described by Osorio and Rock [35]. Most mice survived, and PRV was detected and reactivated in the trigeminal ganglia (TG) of the mice. PRV was reactivated in latently infected (LI) mice in vivo following stimulation with acetylcholine [47].

We have been using our mouse model of latent PRV infection to study $\mathrm{AD}$ in mice with herpes virus infection. However, a great deal of time is required to obtain old mice. Various murine strains, including transgenic (Tg) mice, are used in the field of AD research $[21,36,38$, $41,45,50]$. Some of these show accelerated senescence $[36,45,50]$. It may be possible to replace BALB/c mice with such models in our model of latent infection.

The senescence acceleration model (SAM) mouse, which was established by a Kyoto University group in 1981 [45], is a mouse model of senescence. We are attempting to establish an AD model with latent herpesvirus infection by establishing a model of latent pseudo- rabies virus infection using SAM mice. However, even when mouse strains that show accelerated senescence are used, they take 6 to 12 months to develop senility [44]. For scientific research, a short experimental period is more valuable because it allows a large number of results to be obtained. Thus, we need a mouse model that shows the characteristics of senility at an early stage.

The $\operatorname{Tg} 2576$ mouse is one of the most characterized and widely used mouse models in AD research [12]. It overexpresses a mutant form of APP (isoform 695) with the Swedish mutation, resulting in elevated levels of $A \beta$ and ultimately amyloid plaques [21]. Some reports have shown that mice have impaired spatial learning, a working memory deficit and contextual fear conditioning at less than 6 months of age $[36,50]$. On the other hand, mutations in the genes for APP or two homologous genes, presenilin-1 and presenilin-2 (PS1 and PS2), which produce components of the $\gamma$-secretase complex are linked to familial AD [37]. The PS2 mutations also enhance $\gamma$-secretase activity, leading to the increased production of $\mathrm{A} \beta 42$ [38]. Crossing of these mice resulted in a double Tg mouse (PS2Tg2576), which uniquely develops amyloid plaques [50]. Toda et al. demonstrated the early deposition of A $\beta$ in PS2Tg2576 mice at 2-3 months of age and progressive accumulation in the brains of the mutant mice at $4-5$ months of age [50].

With this background, we aimed to establish an $\mathrm{AD}$ model with latent herpesvirus infection by establishing a model of latent pseudorabies virus infection in double $\mathrm{Tg}$ mice and to examine the kinetics of $\mathrm{A} \beta$ in the brain.

\section{Materials and Methods}

\section{Animals}

Male APP Tg mice (Tg2576) were purchased from Taconic, Inc. (U.S.A.). Female PS2 Tg mice were purchased from Charles Laboratories Japan, Inc., and were used for the production of the PS2Tg2576 mice. Male C57BL/6 mice, which were used as controls, were purchased from Japan SLC, Inc.

\section{Chemicals}

Acetylcholine chloride (ACH) was purchased from Wako Pure Chemical Industries, Ltd., Osaka, Japan.

\section{Cells and viruses}

The YS-81 wild-type PRV strain [23], porcine kidney 
cells (PK-15) [19], and cloned porcine kidney cells (CPK) $[16,25]$ were gifts from Dr. Masashi Sakaguchi of the Chemo-Sero-Therapeutic Research Institute (Kaketsuken) in Kumamoto, Japan. The YS-81 strain was grown in PK-15, and the virus titer was assayed in CPK. The cells were grown in Eagle's minimum essential medium (MEM) containing 5\% fetal bovine serum, 1.5\% $\mathrm{NaHCO}_{3}$, and $0.1 \%$ each of penicillin $\mathrm{G}$ potassium, streptomycin sulphate, and kanamycin sulphate.

\section{Production of PS2Tg2576 mice}

Two male Tg2576 mice and 4 female PS2 Tg mice were mated. At weaning of the juveniles, ear samples were harvested and stored at $-20^{\circ} \mathrm{C}$ until a genotyping test was performed. The PS2Tg2576 mice were selected, and male mice were used for the latent infection test. We accidentally obtained second-generation PS2Tg2576 mice, and these mice were subjected to a genotyping test.

\section{Genotyping test}

The presence of knock-in genes in ear punch specimens was assessed by a PCR that amplified the target sequence. DNA was extracted from ear specimens of 1 $\mathrm{mm}$ in diameter using a MightyAmp Genotyping Kit (Takara Bio, Inc., Kusatsu, Shiga, Japan) in accordance with the manufacturer's protocol. For Tg2576 mice, the DNA samples and oligonucleotide primers were initially heated to $94^{\circ} \mathrm{C}$ for $2 \mathrm{~min}$, denatured at $94^{\circ} \mathrm{C}$ for 1 min, annealed at $56^{\circ} \mathrm{C}$ for $1 \mathrm{~min}$, and extended at $72^{\circ} \mathrm{C}$ for $2 \mathrm{~min}$. The samples were then subjected to 30 cycles of amplification and maintained at $72^{\circ} \mathrm{C}$ for $7 \mathrm{~min}$. For PS2 Tg mice, the DNA samples and oligonucleotide primers were initially heated to $94^{\circ} \mathrm{C}$ for $2 \mathrm{~min}$, denatured at $94^{\circ} \mathrm{C}$ for $1 \mathrm{~min}$, annealed at $56^{\circ} \mathrm{C}$ for $1 \mathrm{~min}$, and extended at $72^{\circ} \mathrm{C}$ for $2 \mathrm{~min}$. The samples were then subjected to 30 cycles of amplification and maintained at $72^{\circ} \mathrm{C}$ for $7 \mathrm{~min}$. The forward primer sequence for $\mathrm{Tg} 2576$ was 5'-AGCGGTAGGACACACACACC-3', and the reverse primer sequence was 5'-AGACGAGCACGACGATGTAC-3'. The forward primer sequence for PS2 $\mathrm{Tg}$ was 5'-AGCGGTAGGACACACACACC-3', and the reverse primer sequence was 5'-AGACGAGCACGACGATGTAC-3'. The MightyAmp DNA Polymerase and MightyAmp Buffer in the MightyAmp Genotyping Kit were used for the DNA polymerase and buffer, respectively. The amplification products in $1.0 \%$ agarose gels were analyzed by electrophoresis.

\section{Latent infection}

Five-week-old mice were passively immunized by ip inoculation with $0.25 \mathrm{ml}$ of anti-PRV swine serum (a gift from Dr. Sakaguchi, Kaketsuken). The final neutralization titer of this serum was 1:128. Thirty min later, the pre-immunized animals were infected ip with $100 \mathrm{LD}_{50}$ of YS-81. The $\mathrm{LD}_{50}$ of YS-81 against mice was determined by the method in our previous study [47]. Mice that survived the challenge were kept for 2 months and used as LI mice. The presence of PRV DNA in the TG of these LI mice was confirmed after they were euthanized [48].

\section{Neutralizing test}

To determine the neutralization titer of anti-PRV swine serum, a neutralizing test was performed. CPK cells were cultured in 96-well microplates. Serial 2-fold dilutions of each serum sample were mixed with the YS-81 strain $\left(200 \mathrm{TCID}_{50} / \mathrm{ml}\right)$ and incubated at $37^{\circ} \mathrm{C}$ for $1 \mathrm{~h}$. As a virus control, the virus solution was incubated in MEM without serum. Each mixture was added to cells in the microplates, and then the microplates were incubated at $37^{\circ} \mathrm{C}$ in $5 \% \mathrm{CO}_{2}$. All wells were examined at days 7 and 11 to observe cytopathic effect appearance. The reciprocal of the highest dilution of the serum that inhibited a cytopathic effec was regarded as the neutralization titer.

\section{Reactivation of latent PRV}

The LI mice were intraperitoneally injected with 2.73 $\mathrm{mg}$ of ACH. As a control, PBS (the solvent of ACH) was intraperitoneally injected into LI mice.

\section{Collection of nasal swab specimens}

During the study, nasal swab specimens were collected as previously described [15]. LI mice were anesthetized with Nembutal (Dainippon Pharmaceutical Co., Ltd., Japan), and $100 \mu 1$ of MEM was injected into one nasal cavity. The wash was collected from the other cavity and mouth with a swab (Men-tip, JCB Industry Limited, Tokyo, Japan); wash specimens were used as nasal swab specimens. The nasal swab specimens were immersed in $100 \mu \mathrm{l}$ of MEM and stored at $-80^{\circ} \mathrm{C}$ until the virus isolation test. Nasal swab specimens were collected daily for 5 days after ACH stimulation.

\section{Detection of viral DNA by PCR}

The presence of latent PRV DNA in nasal swab specimens was assessed by PCR amplification of a 531-bp 
Table 1. The numbers of juvenile Tg2576 male mice and PS2 Tg female mice

\begin{tabular}{lccccccccc}
\hline DATE & 150107 & 150228 & 150407 & 150423 & 150730 & 150804 & 150909 & 151008 & Total \\
\hline TG2576 & 5 & 7 & 1 & 4 & 1 & 3 & 2 & 8 & 31 \\
PS2 & 4 & 5 & 2 & 8 & 2 & 2 & 1 & 1 & 25 \\
PS2Tg2576 & 4 & 6 & 1 & 8 & 2 & 1 & 2 & 0 & 24 \\
$\quad$ Male & 2 & 4 & 1 & 4 & 1 & 1 & 1 & 0 & 14 \\
$\quad$ Female & 2 & 2 & 0 & 4 & 1 & 0 & 1 & 0 & 10 \\
Wild & 5 & 6 & 2 & 3 & 5 & 2 & 2 & 0 & 25 \\
\hline Total & 18 & 24 & 6 & 23 & 10 & 8 & 7 & 9 & 105 \\
\hline
\end{tabular}

Two Tg2576 male mice and 4 PS2 Tg female mice were mated. At weaning of the juveniles, ear samples were harvested and subjected to a genotyping test. The PS2Tg2576 mice were selected, and male mice were used for the latent infection test.

target sequence in the gene encoding PRV gG [52]. DNA was extracted from the specimens with ISOGEN-LS (Wako Pure Chemical Industries, Ltd., Osaka, Japan), in accordance with the manufacturer's protocol. KOD FX Neo was used for DNA polymerase, and the PCR Buffer for KOD FX Neo (Toyobo Co., Ltd., Osaka, Japan) was used as a buffer. The DNA samples and oligonucleotide primers were initially heated to $94^{\circ} \mathrm{C}$ for $2 \mathrm{~min}$, denatured at $94^{\circ} \mathrm{C}$ for $1 \mathrm{~min}$, annealed at $56^{\circ} \mathrm{C}$ for $1 \mathrm{~min}$, and extended at $72^{\circ} \mathrm{C}$ for $2 \mathrm{~min}$. The samples were then subjected to 30 cycles of amplification and maintained at $72^{\circ} \mathrm{C}$ for $7 \mathrm{~min}$. The forward primer sequence was 5'-AGCGGTAGGACACACACACC-3', and the reverse primer sequence was 5'-AGACGAGCACGACGATGTAC- $3^{\prime}$. The amplification products in $1.0 \%$ agarose gels were analyzed by electrophoresis.

\section{Brain sample preparation}

Brain samples were collected after ACH stimulation. Approximately $200 \mu \mathrm{g}$ of brain tissue was minced, then 4 volumes of TBS was added, and then the mixture was homogenized. The homogenate was centrifuged at $15,000 \mathrm{RPM}$ at $4^{\circ} \mathrm{C}$ for $15 \mathrm{~min}$. The supernatant was collected to obtain soluble $A \beta$ for an ELISA. Two volumes of TBS with $5 \mathrm{M}$ guanidine was then added to the precipitate, and the samples were then sonicated for 15 min. Thereafter, the samples were centrifuged at 15,000 $\mathrm{RPM}$ at $4^{\circ} \mathrm{C}$ for $15 \mathrm{~min}$, and the supernatant was collected to obtain insoluble $\mathrm{A} \beta$ for an ELISA.

\section{A $\beta$ detection}

A Human/Rat $\beta$ Amyloid ELISA Kit Wako was used (Wako Pure Chemical Industries, Ltd., Osaka, Japan) in accordance with the manufacturer's protocol. The absorbance at $450 \mathrm{~nm}$ was measured in each well using an iMark $^{\mathrm{TM}}$ Microplate Absorbance Reader (Bio-Rad
Laboratories, Tokyo, Japan). The A $\beta$ concentration was determined from the standard curve.

\section{Statistical analysis}

The significance of the differences in the $A \beta$ concentrations of brain samples was analyzed using Student's $t$-test. The virus excretion data were analyzed using the chi-squared test.

\section{Results}

\section{Production of PS2Tg2576 mice}

The mating of 2 male Tg2576 mice and 4 female PS2 mice produced 105 juveniles. The juveniles were subjected to genotyping. The details of the production are shown in Table 1. Fourteen male double Tg mice were obtained; 11 of them were used for the subsequent experiments.

\section{Establishment of latent infection in PS2Tg2576 mice}

The PS2Tg2576 mice were pre-immunized and infected with YS-81. All of the mice survived the challenge for 2 months (data not shown). They were then used as LI mice. The mice were intraperitoneally injected with $\mathrm{ACH}$ to reactivate the latent PRV.

\section{Accumulation of $A \beta$ in the brain after reactivation}

The levels of $A \beta$ in the brains of mice at two months after infection are shown in Fig. 1. The levels of soluble $A \beta$ did not differ to a statistically significant extent among the tested groups; however, the level of insolubletype $A \beta$ in LI double Tg mice was significantly increased in comparison with the noninfected double Tg mice. A significant difference was also seen between LI double $\mathrm{Tg}$ mice and wild-type mice. 


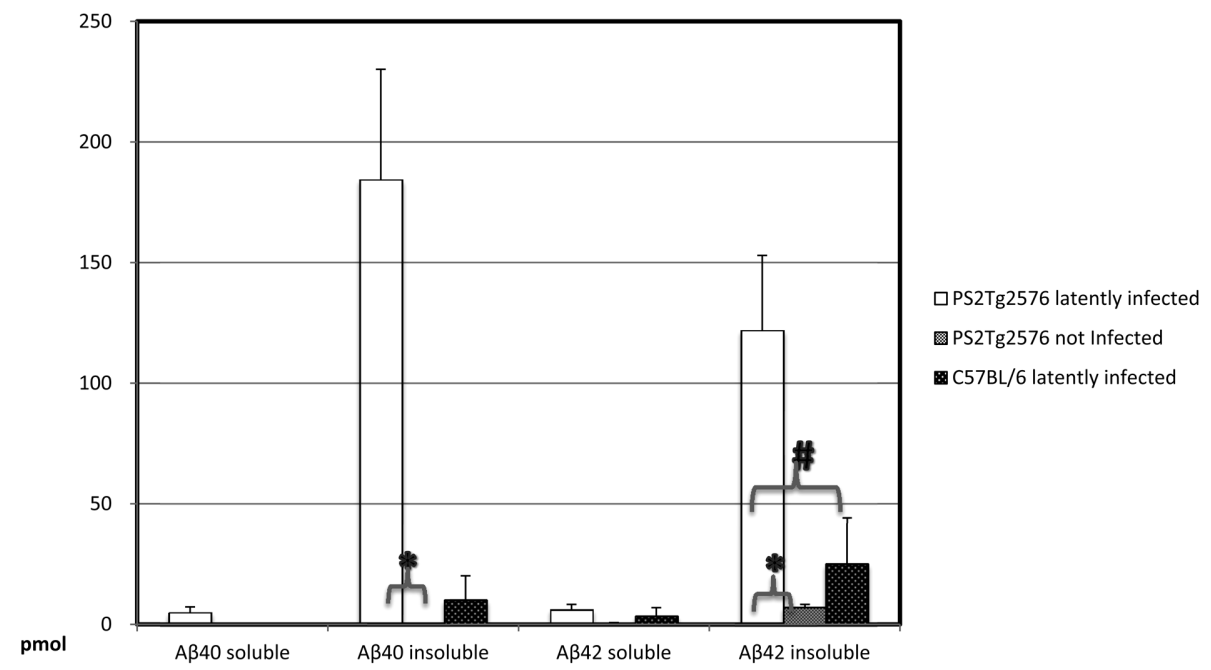

Fig. 1. Amyloid $\beta$ was detected by an ELISA in soluble and insoluble brain samples from double transgenic (Tg) mice at 2 months after latent infection and reactivation. The absorbance in each well was read at $450 \mathrm{~nm}$, and the $A \beta 40$ and $A \beta 42$ concentrations were obtained from the standard curve. The significance of the differences in the concentrations of amyloid $\beta$ in brain samples was analyzed by a $t$-test. *Significant difference between latently infected and noninfected double Tg mice $(P<0.05)$. "Significant difference between latently infected double Tg mice and wild-type mice $(P<0.05)$.

Table 2. Virus excretion in PS2Tg2576 mice latently infected with PRV

\begin{tabular}{|c|c|c|c|c|c|c|c|c|c|c|}
\hline \multirow{2}{*}{ Strain } & \multirow{2}{*}{ Virus infection } & \multicolumn{5}{|c|}{ Virus excretion } & \multicolumn{2}{|c|}{ Total } & \multirow{2}{*}{\multicolumn{2}{|c|}{ Chi-squared value }} \\
\hline & & Day 1 & Day 2 & Day 3 & Day 4 & Day 5 & Positive & Negative & & \\
\hline \multirow[t]{2}{*}{ PS2Tg2576 } & Latently infected & $0 / 8$ & $4 / 8$ & $6 / 8$ & $5 / 8$ & $3 / 6$ & 18 & 20 & 0.001037511 & $\mathrm{a}$ \\
\hline & Noninfected & $0 / 3$ & $0 / 3$ & $0 / 3$ & $0 / 3$ & $0 / 3$ & 0 & 15 & 0.000136546 & $\mathrm{~b}$ \\
\hline C57BL/6 & Latently infected & $1 / 3$ & $0 / 3$ & $1 / 3$ & $1 / 3$ & $1 / 3$ & 4 & 11 & 0.168260983 & $\mathrm{c}$ \\
\hline
\end{tabular}

Data on virus excretion are shown as the number of mice that showed virus presence in nasal swabs by PCR. Total means the total number of mice that were positive or negative for virus presence in nasal swabs from Day 1 to Day 5 . The chi-squared values were compared. a: The PS2Tg2576 latently infected group versus noninfected group. b: The PS2Tg2576 noninfected group versus the C57BL/6 latently infected group. c: The PS2Tg2576 latently infected group versus the C57BL/6 latently infected group.

\section{Virus excretion in nasal swabs}

Nasal swab specimens were collected, and the presence of PRV DNA was confirmed by a PCR. As shown in Table 2, the viral DNA was identified. The nasal swab specimens were collected at the time of reactivation and were tested for the presence of PRV by a PCR. PRV reactivation was confirmed in the specimens collected daily for 5 days after $\mathrm{ACH}$ stimulation. The reactivation rates of the Tg and wild-type mice did not differ in this test. Viral DNA was not detected on day 0 (the day of reactivation; data not shown). We did not determine the threshold because this test was for quality, not for quantity.

\section{Viral DNA in TG}

The presence of PRV DNA in the TG of these LI mice was confirmed by PCR after the mice were euthanized (data not shown). The presence of PRV DNA in the TG of mice that were euthanized at 2 months after latent infection was proven by a PCR (data not shown).

\section{Second-generation PS2Tg2576 mice}

We accidentally obtained second-generation PS2Tg2576 mice, and we performed genotyping on them. The gene derived from PS2 was determined. However, the gene derived from Tg2576 was found to have been dropped in the second generation of juveniles (data not shown). 


\section{Discussion}

One hundred five juvenile mice were obtained in the present study, and 24 were PS2Tg2576 mice. The ratios of PS2, Tg2576, PS2Tg2576, and wild-type mice were almost the same and followed Mendel's law. This meant that there were no breeding problems.

By determining the PRV $L_{50}$, the double Tg mice were latently infected in the same manner as $\mathrm{BALB} / \mathrm{c}$ mice [47]. The viral $\mathrm{LD}_{50}$ of double $\mathrm{Tg}$ mice was similar to that of C57BL/6 mice, the background strain of the Tg2576 and PS2 Tg mice, as shown in our previous report [49]. A latent infection model was constructed by inoculating the mice with $100 \mathrm{LD}_{50}$ of PRV YS-81. This means that our mouse model can be widely applied in life science research because it can be applied to many types of Tg mice that descend from C57BL/6 mice. Virus reactivation was observed in LI double Tg mice, as was observed in other strains [49]. It was determined that latent PRV infection was established in the PS2Tg2576 mice.

The results showed that accumulation of insoluble $A \beta$ was increased in the brain of PS2Tg2576 mice with the reactivation of latent PRV but not in uninfected PS2Tg2576 mice or LI C57BL/6 mice (Fig. 1).

As shown in Fig. 1, the reactivation group showed significantly higher levels of insoluble $A \beta$, which indicates that reactivation of $L I$ herpesvirus might cause the severity of AD to increase $[6,13]$.

There is a limitation of the present model, and it would be better to combine the present model with other models to evaluate the disease symptoms. If the present model is used, it might be necessary to increase the study period by a number of months in order to identify typical behaviors. The increase in the accumulation of $A \beta$ that was typically observed in this model appeared after only two months; thus, PS2Tg2576 mice can be used to investigate the accumulation of $A \beta$ in the brain in dementia research. This short-term study shows the merit of the PS2Tg2576 mouse model.

In the present study, we accidentally obtained secondgeneration PS2Tg2576 mice. The gene derived from $\operatorname{Tg} 2576$ was found to have been dropped in the second generation of juveniles (data not shown). The reason for this was not clear; however, this result indicates that PS2 and $\mathrm{Tg} 2576$ mice should be mated for each test in order to obtain PS2Tg2576 mice. This might be a barrier to research.
In the present study, PRV was used to establish latent herpesvirus infection in our mouse model. HSV belongs to the Simplexvirus genus, while PRV belongs to the Varicellovirus genus, which includes varicella zoster virus [22]. Although the relationship between HSV and AD has been reported, a few studies have suggested a relationship between varicella zoster virus and AD [11, 28-30]. It seems to depend on the affinity to the brain; however, we do not have any data on this. PRV has high affinity to the brain and is used as a tracer in the brain via the nervous system $[8,9]$.

There are some reports on models of latent HSV infection [7, 27]; however, in these studies, the researchers only harvested ganglia that were latently infected with HSV and reactivated the virus in vitro [31, 53]. On the other hand, we could reactivate the latent virus in vivo in our model of latent PRV infection [47]. Our model offers an advantage in that we could observe the dynamism in the mouse brain during the reactivation of latent PRV.

In this report, we showed that PS2Tg2576 mice were useful to a limited extent for the analysis of $\mathrm{AD}$ in an experimental mouse model with latent herpesvirus infection, which was ready for use after only two months. This model will be useful for assessing AD in the early experimental period.

\section{Acknowledgments}

We would like to thank to Dr. Masashi Sakaguchi in the Chemo-Sero-Therapeutic Research Institute (Kaketsuken) for giving us the YS-81 wild-type PRV strain, porcine kidney cells (PK-15), cloned PK-15 cells (CPK), and anti-PRV swine serum. This study was supported in part by grants from the Ministry of Education, Culture, Sports, Science and Technology (MEXT) and JSPS KAKENHI Grant Number 26430096.

\section{References}

1. Ahmed, R. and Stevens, J.G. 1990. Viral persistence, pp. 241-266. In: Virology. (Fields, B.N. and Knipe, D.M. eds.), Raven Press, New York.

2. Amano, N., Matsuishi, T., Suzuki, K., Yokoi, S., Saitoh, A., and Yagishita, S. 1984. [Ultrastructural study of the neuronal lipofuscin--an autopsy case of familial Alzheimer's disease]. No To Shinkei 36: 657-663. (in Japanese) [Medline]

3. Arnáiz, E. and Almkvist, O. 2003. Neuropsychological features of mild cognitive impairment and preclinical Alzheim- 
er's disease. Acta Neurol. Scand. Suppl. 107: 34-41. [Medline] [CrossRef]

4. Bäckman, L., Jones, S., Berger, A.K., Laukka, E.J., and Small, B.J. 2004. Multiple cognitive deficits during the transition to Alzheimer's disease. J. Intern. Med. 256: 195-204. [Medline] [CrossRef]

5. Ball, M.J. 1982. Limbic predilection in Alzheimer dementia: is reactivated herpesvirus involved?. Can. J. Neurol. Sci. 9: 303-306. [Medline] [CrossRef]

6. Bao, F., Wicklund, L., Lacor, P.N., Klein, W.L., Nordberg, A., and Marutle, A. 2012. Different $\beta$-amyloid oligomer assemblies in Alzheimer brains correlate with age of disease onset and impaired cholinergic activity. Neurobiol. Aging 33: 825.e1-825.e13. [Medline] [CrossRef]

7. BenMohamed, L., Osorio, N., Khan, A.A., Srivastava, R., Huang, L., Krochmal, J.J., Garcia, J.M., Simpson, J.L., and Wechsler, S.L. 2016. Prior Corneal Scarification and Injection of Immune Serum are Not Required Before Ocular HSV-1 Infection for UV-B-Induced Virus Reactivation and Recurrent Herpetic Corneal Disease in Latently Infected Mice. Curr. Eye Res. 41: 747-756. [Medline] [CrossRef]

8. Card, J.P., Rinaman, L., Lynn, R.B., Lee, B.H., Meade, R.P., Miselis, R.R., and Enquist, L.W. 1993. Pseudorabies virus infection of the rat central nervous system: ultrastructural characterization of viral replication, transport, and pathogenesis. J. Neurosci. 13: 2515-2539. [Medline]

9. Carr, D.B., O’Donnell, P., Card, J.P., and Sesack, S.R. 1999. Dopamine terminals in the rat prefrontal cortex synapse on pyramidal cells that project to the nucleus accumbens. $J$. Neurosci. 19: 11049-11060. [Medline]

10. Centifanto-Fitzgerald, Y., Caldwell, D.R., and Yates, F. 1987. Herpes simplex virus: recurrent and nonrecurrent strains. Proc. Soc. Exp. Biol. Med. 185: 484-492. [Medline] [CrossRef]

11. Chidiac, C. and Braun, E. 2002. [Atherosclerosis, multiple sclerosis, and Alzheimer's disease: what role for Herpesviridae?]. Pathol. Biol. (Paris) 50: 463-468. (in French) [Medline] [CrossRef]

12. Elder, G.A., Gama Sosa, M.A., and De Gasperi, R. 2010. Transgenic mouse models of Alzheimer's disease. Mt. Sinai J. Med. 77: 69-81. [Medline] [CrossRef]

13. Esparza, T.J., Zhao, H., Cirrito, J.R., Cairns, N.J., Bateman, R.J., Holtzman, D.M., and Brody, D.L. 2013. Amyloid- $\beta$ oligomerization in Alzheimer dementia versus high-pathology controls. Ann. Neurol. 73: 104-119. [Medline] [CrossRef]

14. Förstl, H. and Kurz, A. 1999. Clinical features of Alzheimer's disease. Eur. Arch. Psychiatry Clin. Neurosci. 249: 288290. [Medline] [CrossRef]

15. Franklin, C.L., Pletz, J.D., Riley, L.K., Livingston, B.A., Hook, R.R. Jr., and Besch-Williford, C.L. 1999. Detection of cilia-associated respiratory (CAR) bacillus in nasal-swab specimens from infected rats by use of polymerase chain reaction. Lab. Anim. Sci. 49: 114-117. [Medline]

16. Fukusho, A., Ogawa, N., Yamamoto, H., Sawada, M., and Sazawa, H. 1976. Reverse plaque formation by hog cholera virus of the GPE-strain inducing heterologous interference. Infect. Immun. 14: 332-336. [Medline]
17. Goedert, M., and Spillantini, M.G. 2006. A century of Alzheimer's disease. Science 314: 777-781. [Medline] [CrossRef]

18. Gu, L. and Guo, Z. 2013. Alzheimer's A $\beta 42$ and A $\beta 40$ peptides form interlaced amyloid fibrils. J. Neurochem. 126: 305-311. [Medline] [CrossRef]

19. Harris, M. 1959. Growth measurements on monolayer cultures with an electronic cell counter. Cancer Res. 19: 10201024. [Medline]

20. Hashimoto, M. 2015. Life style and dementia: diet and exercise in the prevention of dementia. Dement. Jpn. 29: 9-25.

21. Hsiao, K., Chapman, P., Nilsen, S., Eckman, C., Harigaya, Y., Younkin, S., Yang, F., and Cole, G. 1996. Correlative memory deficits, Abeta elevation, and amyloid plaques in transgenic mice. Science 274: 99-102. [Medline] [CrossRef]

22. ICTV 2016 Taxonomy. http://ictvonline.org/virusTaxonomy. asp.

23. Itakura, C., Nakatsuka, J., and Goto, M. 1981. An incidence of pseudorabies (Aujeszky's Disease) in piglets in Japan. Nippon Juigaku Zasshi 43: 923-927. [Medline] [CrossRef]

24. Khachaturian, Z.S. and Radebaugh, T.S. 1996. Alzheimer's Disease: Cause(s), Diagnosis, Treatment, and Care, CRC, Boca Raton, Fla, USA.

25. Komaniwa, H., Fukusho, A., and Shimizu, Y. 1981. Micro method for performing titration and neutralization test of hog cholera virus using established porcine kidney cell strain. Natl. Inst. Anim. Health Q. (Tokyo) 21: 153-158. [Medline]

26. Kristen, H., Santana, S., Sastre, I., Recuero, M., Bullido, M.J., and Aldudo, J. 2015. Herpes simplex virus type 2 infection induces AD-like neurodegeneration markers in human neuroblastoma cells. Neurobiol. Aging 36: 2737-2747. [Medline] [CrossRef]

27. Laycock, K.A., Lee, S.F., Brady, R.H., and Pepose, J.S. 1991. Characterization of a murine model of recurrent herpes simplex viral keratitis induced by ultraviolet B radiation. Invest. Ophthalmol. Vis. Sci. 32: 2741-2746. [Medline]

28. Lin, W.R., Casas, I., Wilcock, G.K., and Itzhaki, R.F. 1997. Neurotropic viruses and Alzheimer's disease: a search for varicella zoster virus DNA by the polymerase chain reaction. J. Neurol. Neurosurg. Psychiatry 62: 586-589. [Medline] [CrossRef]

29. Lin, W.R., Shang, D., and Itzhaki, R.F. 1996. Neurotropic viruses and Alzheimer disease. Interaction of herpes simplex type 1 virus and apolipoprotein $\mathrm{E}$ in the etiology of the disease. Mol. Chem. Neuropathol. 28: 135-141. [Medline] [CrossRef]

30. MacDonald, A.B. 2007. Alzheimer's disease Braak Stage progressions: reexamined and redefined as Borrelia infection transmission through neural circuits. Med. Hypotheses 68: 1059-1064. [Medline] [CrossRef]

31. Mador, N., Braun, E., Haim, H., Ariel, I., Panet, A., and Steiner, I. 2003. Transgenic mouse with the herpes simplex virus type 1 latency-associated gene: expression and function of the transgene. J. Virol. 77: 12421-12429. [Medline] [CrossRef]

32. Martin, J.R. and Suzuki, S. 1987. Inflammatory sensory polyradiculopathy and reactivated peripheral nervous sys- 
tem infection in a genital herpes model. J. Neurol. Sci. 79: 155-171. [Medline] [CrossRef]

33. Middleton, P.J., Petric, M., Kozak, M., Rewcastle, N.B., and McLachlan, D.R. 1980. Herpes-simplex viral genome and senile and presenile dementias of Alzheimer and Pick. Lancet 315: 1038. [Medline] [CrossRef]

34. Openshaw, H., Asher, L.V., Wohlenberg, C., Sekizawa, T., and Notkins, A.L. 1979. Acute and latent infection of sensory ganglia with herpes simplex virus: immune control and virus reactivation. J. Gen. Virol. 44: 205-215. [Medline] [CrossRef]

35. Osorio, F.A., and Rock, D.L. 1992. A murine model of pseudorabies virus latency. Microb. Pathog. 12: 39-46. [Medline] [CrossRef]

36. Price, D.L. and Sisodia, S.S. 1998. Mutant genes in familial Alzheimer's disease and transgenic models. Annu. Rev. Neurosci. 21: 479-505. [Medline] [CrossRef]

37. Rogaev, E.I., Sherrington, R., Rogaeva, E.A., Levesque, G., Ikeda, M., Liang, Y., Chi, H., Lin, C., Holman, K., Tsuda, T., Mar, L., Sorb, S., Nacmias, B., Piacentini, S., Amaducci, L., Chumakov, I., Cohen, D., Lannfelt, L., Fraser, P.E., Rommens, J.M., and St George-Hyslop, P.H. 1995. Familial Alzheimer's disease in kindreds with missense mutations in a gene on chromosome 1 related to the Alzheimer's disease type 3 gene. Nature 376: 775-778. [Medline] [CrossRef]

38. Sawamura, N., Morishima-Kawashima, M., Waki, H., Kobayashi, K., Kuramochi, T., Frosch, M.P., Ding, K., Ito, M., Kim, T.W., Tanzi, R.E., Oyama, F., Tabira, T., Ando, S., and Ihara, Y. 2000. Mutant presenilin 2 transgenic mice. A large increase in the levels of Abeta 42 is presumably associated with the low density membrane domain that contains decreased levels of glycerophospholipids and sphingomyelin. J. Biol. Chem. 275: 27901-27908. [Medline]

39. Selkoe, D.J. 2001. Alzheimer's disease: genes, proteins, and therapy. Physiol. Rev. 81: 741-766. [Medline] [CrossRef]

40. Serrano-Pozo, A., Frosch, M.P., Masliah, E., and Hyman, B.T. 2011. Neuropathological alterations in Alzheimer disease. Cold Spring Harb. Perspect. Med. 1: a006189. [Medline] [CrossRef]

41. Shimeld, C., Hill, T.J., Blyth, W.A., and Easty, D.L. 1990. Reactivation of latent infection and induction of recurrent herpetic eye disease in mice. J. Gen. Virol. 71: 397-404. [Medline] [CrossRef]

42. Stevens, J.G. 1989. Human herpesviruses: a consideration of the latent state. Microbiol. Rev. 53: 318-332. [Medline]

43. Suzuki, N., Cheung, T.T., Cai, X.D., Odaka, A., Otvos, L. Jr., Eckman, C., Golde, T.E., and Younkin, S.G. 1994. An increased percentage of long amyloid beta protein secreted by familial amyloid beta protein precursor (beta APP717) mutants. Science 264: 1336-1340. [Medline] [CrossRef]

44. Takeda, T., Hosokawa, M., and Higuchi, K. 1994. Senescence-accelerated mouse (SAM). A novel murine model of aging. Internstl. Cogr. Ser. 1062: 15-22.

45. Takeda, T., Hosokawa, M., Takeshita, S., Irino, M., Higuchi, K., Matsushita, T., Tomita, Y., Yasuhira, K., Hamamoto, H., Shimizu, K., Ishii, M., and Yamamuro, T. 1981. A new murine model of accelerated senescence. Mech. Ageing Dev. 17: 183-194. [Medline] [CrossRef]

46. Tanaka, S., Imamura, T., Sakaguchi, M., Mannen, K., and Matsuo, K. 1996. Acetylcholine activates latent pseudorabies virus in pigs. Arch. Virol. 141: 161-166. [Medline] [CrossRef]

47. Tanaka, S., Imamura, T., Sakaguchi, M., and Mannen, K. 1998. Acetylcholine reactivates latent pseudorabies virus in mice. J. Virol. Methods 70: 103-106. [Medline] [CrossRef]

48. Tanaka, S. and Mannen, K. 2004. Role of IL-6 and IL-1 $\beta$ in reactivation by acetylcholine of latently infecting pseudorabies virus. Exp. Anim. 53: 457-461. [Medline] [CrossRef]

49. Tanaka, S. 2016. Establishment of the Aujeszky's disease virus latent infection model using some of mouse strains. Kyushu J. Exp. Anim. 32: 7-11.

50. Toda, T., Noda, Y., Ito, G., Maeda, M., and Shimizu, T. 2011. Presenilin-2 mutation causes early amyloid accumulation and memory impairment in a transgenic mouse model of Alzheimer's disease. J. Biomed. Biotechnol. 2011: 617974. [Medline] [CrossRef]

51. Uchida, K., Meno, K., Suzuki, H., Aakazu, H., Mizukami, K., and Asada, T. 2013. Peripheral biomarker for mild cognitive imparment and Alzheimer's disease. Dement. Jpn. 27: 271-276.

52. Wozniak, M.A., Mee, A.P., and Itzhaki, R.F. 2009. Herpes simplex virus type 1 DNA is located within Alzheimer's disease amyloid plaques. J. Pathol. 217: 131-138. [Medline] [CrossRef]

53. Yao, H.W., Ling, P., Tung, Y.Y., Hsu, S.M., and Chen, S.H. 2014. In vivo reactivation of latent herpes simplex virus 1 in mice can occur in the brain before occurring in the trigeminal ganglion. J. Virol. 88: 11264-11270. [Medline] [CrossRef] 